EESTI NSV TEADUSTE AKADEEMIA TOIMETISED. XIII KÖIDE.

FOUSIKA-MATEMAATIKA- JA TEHNIKATEADUSTE SEERIA. 1964, NR. 1

НЗВЕСТИЯ АҚАДЕМИИ НАУК ЭСТОНСКОН ССР. ТОМ ХІІІ

СЕРИЯ ФИЗНКО-МАТЕМАТИЧЕСКНХ И ТЕХННЧЕСКНХ НАУК. 1964, No 1

\title{
ОПРЕДЕЛЕНИЕ ХИМИЧЕСКОГО СОСТАВА СЛАНЦЕВОГО БЕНЗИНА ТУННЕЛЬНЫХ ПЕЧЕИ ГАЗОХРОМАТОГРАФИЧЕСКИМ МЕТОДОМ
}

о. ЭИЗЕН,

кандидат технических наук

\section{Э. АРУМЕЕЛ}

Индивидуальный химическнй состав бензина туннельных печей Қивнылн определен до фракции $150^{\circ}$ [']. Целью настоящей работы явился анализ бензиновой фракцни туннельных печей, выкипающей до $200^{\circ} \mathrm{C}$. Объектом настоящего нсследования служили продукты туннельных печей Кохтла-Ярве и I и IV печей Қивныли. Более подробно исследовались бензины IV туннельной печи. Для выяснения возможных различий химического состава бензиновой фракции в завнсимости от времени рабочего пернода, анализ бензина проводился в начале, середине и конце рабочего цикла туннельчой печи.

Оказалось целесообразным анализировать отдельно низкокипящий газбензнн и бо. лее высококипящую часть бензина.

Пробы газбензинов туннельных печей Кивиыли взяты только из первсй ступенн конденсации, так как более легкая часть газбензина содержит промывной бензин, количество которого трудно установить [2]. В туннельных печах Қохтла-Ярве газбензином является наиболее легкая конденснрованная фракция [0].

Таблица 1

Характернстика бензннов туннельных печей

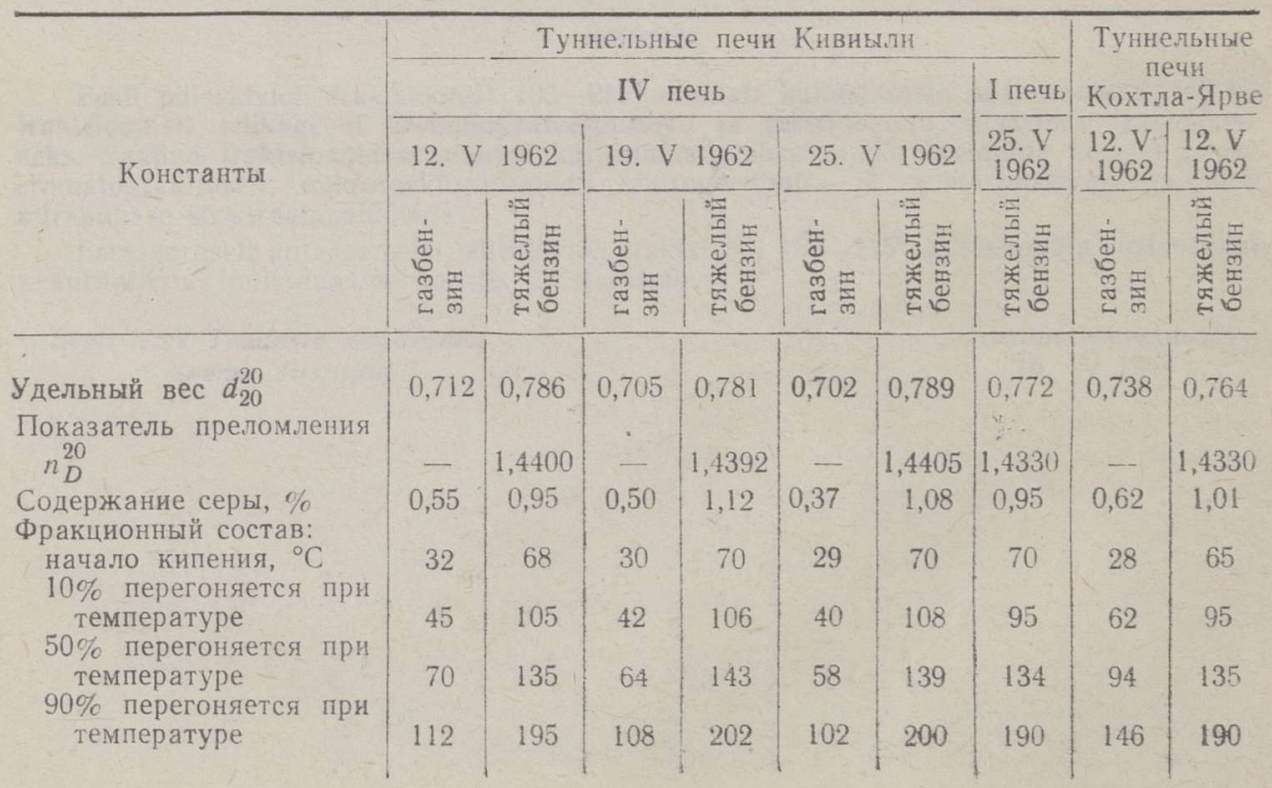


Исходным сырьем для анализа более высококипяшей частн бензина служила смесь бенэина и легкого масла туннельных печей Кивиыли в пропорции, соответствующей промышленному выходу этих продуктов, и тегкое масло туннельных печей Кохтла-Ярве. После дефенолировання перегоняли нз нсходного сырья фракцию, выкнпающую до $200^{\circ}$. В дальнейшем будем эту фракцию называть тяжелым бензином. Характеристнка газбензинов и тяжелых бензинов приведена в табл. 1.

В настоящей работе исследование осуществлялось в основном газохроматографнческнм методом, на газохроматографе УХ-1 [4]. Характеристика используемых колонок, жидких фаз и условнй анализа приведена в табл. 2.

Идентификацня углеводородов осуществлялась с помощью эталонных веществ.

Нэмерение площади под пиками производилось путем умножения высоты пика на его ширнну, нзмеренную на половине высоты. Содержанне отдельных компонентов рассчнтывалось в процентах от суммы всех площадей.

Поскольку состав газбензинов является относительно несложным и газохроматографический анализ низкокипящих фракций бензинов довольно хорошо нсследован и легко осушествим, то стало возможным анализировать исследуемые пробы газбензннов пряно газохроматографнческим методом без предварительной ректифнкацин н разделения на группы углеводородов с помощью жидкостно-адсорбционной хроматографин. На рис. 1 изображена хроматограмиа газо́ензина.

Результаты анализа газбензинов приведены в табл. 3.

Аналнз тяжелого бензина с применением только газохроматографического метода не дал удовлетворительных результатов. Присутствующие в бензине парафнновые, нафтеновые, олефиновые и ароматические углеводороды дают ряд совпадающих пиков. Поэтому в настоящей работе тяжелый бензин разделялся методом жидкостно-адсорбционной хрожагографин на группы углеводородов, и последние анализировались газохроматографнческим методом.

Жндкостно-адсорбционная хроматография осуществлялась на силикагеле КСМ, который для уменьшения полимеризации углеводородов, предварительно обрабатывался соляной кислотой и перекисью водорода [5]. Весовое отношение исследованной пробы н силикагеля составляло $1: 20$.

Таб́лищุa 2

Характернстнка газохроматографнческих колонок, прнменяемых для аналнза сланцевых бензннов

\begin{tabular}{|c|c|c|c|c|c|}
\hline & Ко.тонка & № 1 & o 2 & № 3 & 으 4 \\
\hline Кидкая ф & фаза & $\begin{array}{l}\text { ацетонилаце- } \\
\text { тон } 20 \%\end{array}$ & $\begin{array}{l}\text { дифенил- } \\
\text { формамид } \\
20 \%\end{array}$ & $\begin{array}{c}\beta, \beta^{\prime} \text {-тнодн- } \\
\text { пропио- } \\
\text { нитрил } 20 \%\end{array}$ & $\begin{array}{l}\text { полиэтилен- } \\
\text { гликоль } 20 \%\end{array}$ \\
\hline
\end{tabular}

Твердый носитель

Длина колонкн, н

Внутренннй днамегр колонки, ни

Температура колонок, ${ }^{\circ} \mathrm{C}$

Скорость, газа-носнтеля (водород), нл/лик

Анализнруемая группа углеводородов$$
\text { B }
$$

Давление в начале колонкн, атм

в конце колонкн, ат

Қоличество пробы, $\mu$ л

IIкала самопнсца, мв диатомитовый кирпич Апрелевского завода с величнной зерна $0,2-0,3$ мм
6,8

3

20

50

газбензнн

газбензин, парафнны, нафтены, о.тефнны

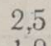

2,0
1,0

5

$1,2,5,25$
2,5

1,0

10

$1,2,5,25$

\begin{tabular}{c|r}
6 & 6 \\
4 & 4 \\
100,150 & 15
\end{tabular}

36 ароматические углеводороды

роматические углеводороды

$5-10$

$1,2,5,25$
6 4 50

60
$1,2,5,25$ 
Tаблища 3

Состав газбензинов

\begin{tabular}{|c|c|c|c|c|c|c|}
\hline \multirow[b]{2}{*}{ № } & \multirow[b]{2}{*}{ Соедннение } & \multirow[b]{2}{*}{$\begin{array}{c}\text { Относитель- } \\
\text { ное время } \\
\text { удерживания }\end{array}$} & \multicolumn{3}{|c|}{ Газбензнн Кнвныли } & \multirow[b]{2}{*}{$\begin{array}{c}\text { Газбензин } \\
\text { Кохтла-Ярве } \\
\text { 12. V } 1962\end{array}$} \\
\hline & & & 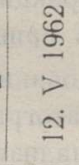 & $\begin{array}{l}\text { ळै } \\
\text { क } \\
\text { के }\end{array}$ & $\frac{81}{8}$ & \\
\hline 1 & 2 & 3 & 4 & 5 & 6 & 7 \\
\hline
\end{tabular}

Парафнновые углеводороды
1. Этан
2. Пропан
3. Бутан
4. Пентан
5. Гексан
6. Гептан
7. Октан
8. Нонан
9. Декан

\begin{tabular}{r|r|r|r|r}
4 & 0,2 & - & - & - \\
10 & 0,6 & 0,6 & 0,6 & - \\
34 & 2,1 & 4,0 & 4,5 & 0,9 \\
100 & 5,8 & 9,8 & 13,4 & 3,3 \\
283 & 9,4 & 9,5 & 10,6 & 8,0 \\
760 & 6,7 & 5,0 & 2,6 & 7,2 \\
- & 2,7 & 2,0 & 0,7 & 4,6 \\
- & 0,9 & - & - & 2,1 \\
- & 0,4 & - & - & 0,2 \\
\hline B с г о & 28,8 & 30,9 & 32,4 & 26,3
\end{tabular}

Изопарафиновые углеводороды

10. 2-Метнлбутан

\begin{tabular}{l|l|l|l|l|}
73 & 0,5 & 1,0 & 1,6
\end{tabular}

Н афтеновые углеводороды

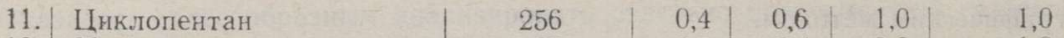

\begin{tabular}{l|l|l|l|r|r|} 
12. Mетнлцнклопентан & 482 & 2,5 & 2,4 & 2,0 & 1,8
\end{tabular}

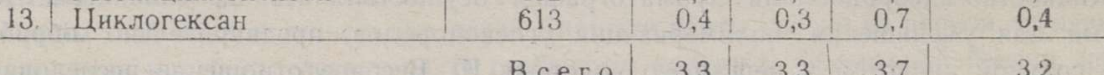

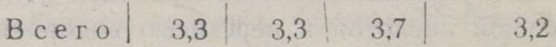

1-олефиновые углеводороды

\begin{tabular}{l|l|r|r|r|r|r} 
14. Пропен & 19 & 0,5 & 0,5 & 0,5 & 0,1 \\
15. & Бутен-1 & 53 & 1,9 & 2,5 & 2,7 & 0,7 \\
16. Пентен-1 & 150 & 4,9 & 8,7 & 10,8 & 2,9 \\
17. Гексен-1 & 428 & 10,3 & 11,7 & 13,5 & 10,6 \\
18. Гептен-1 & - & 9,8 & 6,4 & 4,1 & 13,2 \\
19. Октен-1 & - & 4,6 & 2,9 & 1,2 & 7,6 \\
20. Нонен-1 & - & 0,2 & - & - & 1,9 \\
21. Децен-1 & - & - & - & - & 0,3 \\
\hline
\end{tabular}

2,3 - олефиновые углеводороды

\begin{tabular}{|c|c|c|c|c|c|}
\hline Бутен-2 (транс) & 70 & 0,8 & 1,3 & 1,5 & 0,4 \\
\hline Бутен-2 (цис) & 83 & 0,6 & 0,9 & 1,3 & 0,3 \\
\hline Пентен-2 (транс) & 185 & 3,6 & 4,2 & 5,0 & 2,2 \\
\hline Пентен-2 (цис) & 200 & 2,2 & 2,4 & 2,6 & 1,7 \\
\hline Гексены & 440 & 2,3 & 2,5 & 3,0 & 3,0 \\
\hline Гептены & - & 6,7 & 3,8 & 2,9 & 4,8 \\
\hline Октены & - & 2,6 & 1,7 & 0,8 & 2,9 \\
\hline & & 18,8 & 16,8 & 17,1 & 15,3 \\
\hline
\end{tabular}

Изоолефиновые углеводороды

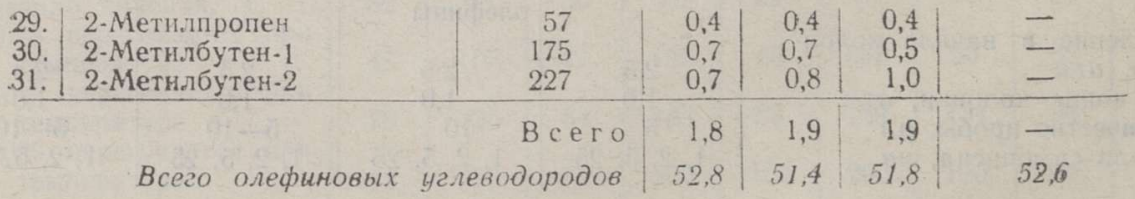


(Прсдолжемие табл. 3)

\begin{tabular}{l|l|l|l|l|l|l|l}
\hline 1 & 2 & 3 & 4 & 5 & 6 & 7 \\
\hline
\end{tabular}

Циклоолефнновые углеводороды
32. Цнклопентен
370
1,7
$2,4 \mid 2,6$

Диолефиновые углеводороды

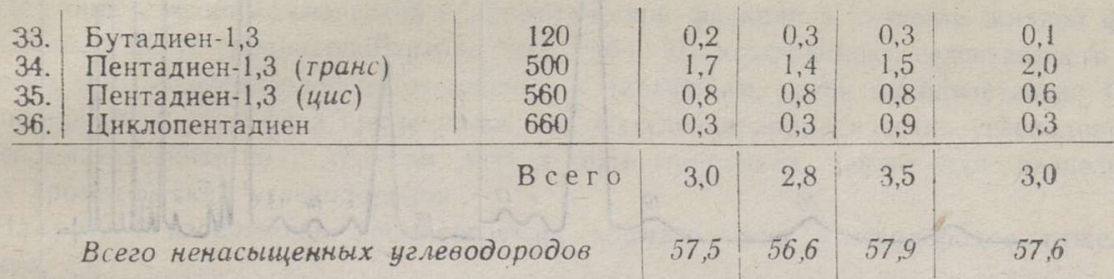

Ароматическне углеводороды

\begin{tabular}{l|l|r|r|r|r} 
37. Бензол & & - & - & - & 1,6 \\
38. Метнлбензол & & - & - & - & 2,3 \\
\hline & B сего & - & - & - & 3,9 \\
Сернистые & & 1,8 & 1,6 & 1,2 & 1,9 \\
Нендентнфнцированные соедннения & 8,1 & 6,6 & 3,2 & 7,1 \\
\hline
\end{tabular}

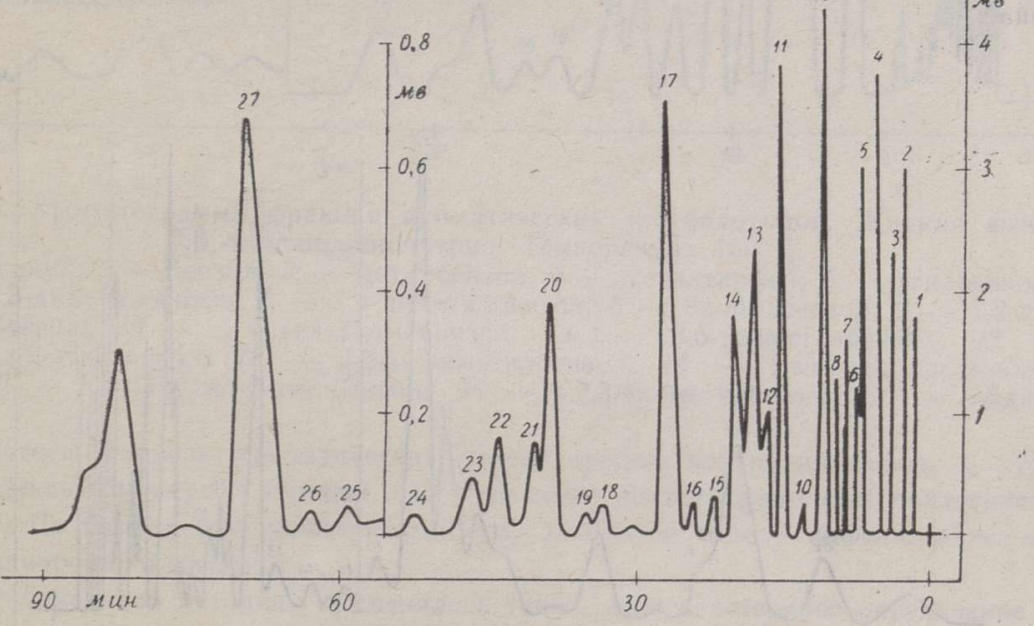

Рнс. 1. Хроматограмма газб́ензнна туннельной печи Кнвныли. Жиякая фаза: ацетоннлацетон $20 \%$

1 - воздух; 2 - пропан; 3 - пропен; 4 - бутан; 5 - бутен-1; 6 - 2-метнлпропен; 7 - бутен-2 (транс); 8 - бутен-2 (цис); 9 пентан; 10 - бутадиен-1,3; 11 - пентен-1; 12 - 2-метнлбутен-1; 13 - пентен-2 (транс); 14 - пентен-2 (цис); 15 -- 2-метнлбутен-2; 16 - циклопентан; 17 - гексан; 18 - цнклопентен; 19 - нзопрен; 20 - гексен-1;21 - гексен-2; 22 - метилцнклопентан; 23 - пентадиен-1,3 (трахс); 24 - пентадиен-1,3 (цис); 25 - циклогексан; 26 - циклопентаднен; 27 - гептан. 


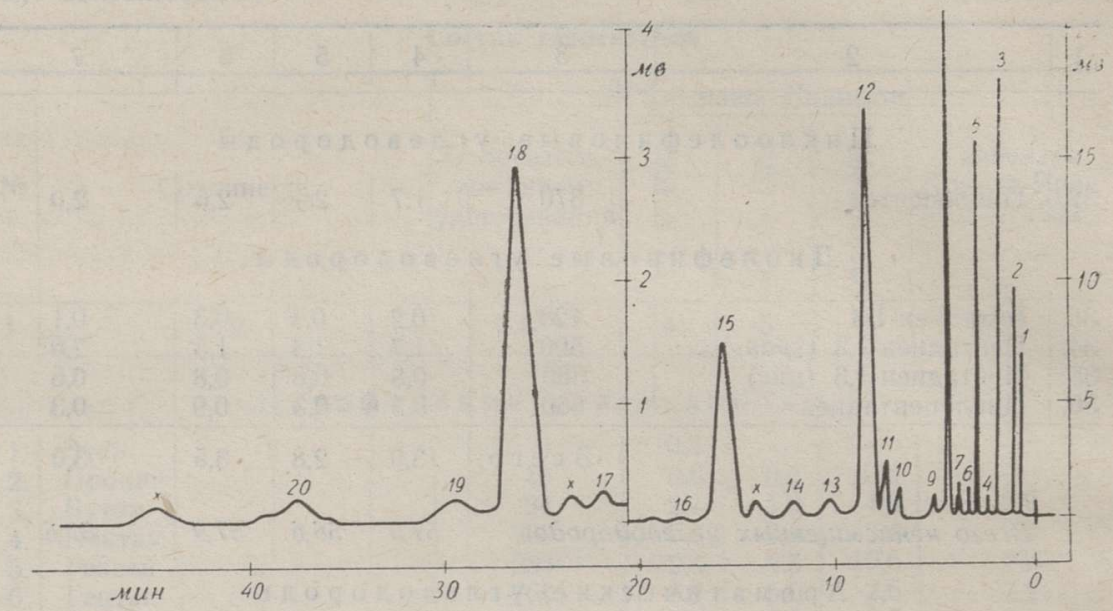

Рис. 2. Хроматограмма фракцин парафиновых углеводородов. Жидкая фаза: дифенилформамид $20 \%$.

1 - воздух; 2 - бутан; 3 - пентан; 4 - пентен-1; 5 - гексан;

6 - гексен-1; 7 - метилциклопентан; 8 - гептан; 9 - циклогексан; 10 - 2-метилгептан; 11 - метилциклогексан; 12 - октан; 13 октен-1; 14 - 2-метилоктан; $15-$ нонан; $16-$ нонен-1; $17-2$-метилнонан; 18 - декан; $19-$ децен-1; 20 - 2-метилдекан; $x-$ нензвестные.

На рис. 2 изображена хроматограмма парафиновой фракции тяжелого бензнна.

Из данных рис. 2 видно, что основными компонентами являются здесь парафины с нормальной цепью. В меньшем количестве представлены нафтены и изопарафины. Количество олефннов, попавших в парафиново-нафтеновую фракцию, весьма невелико.

$\mathrm{Ha}$ рис. 3 изображена хроматограмма олефиновых углеводородов тяжелого бензина.

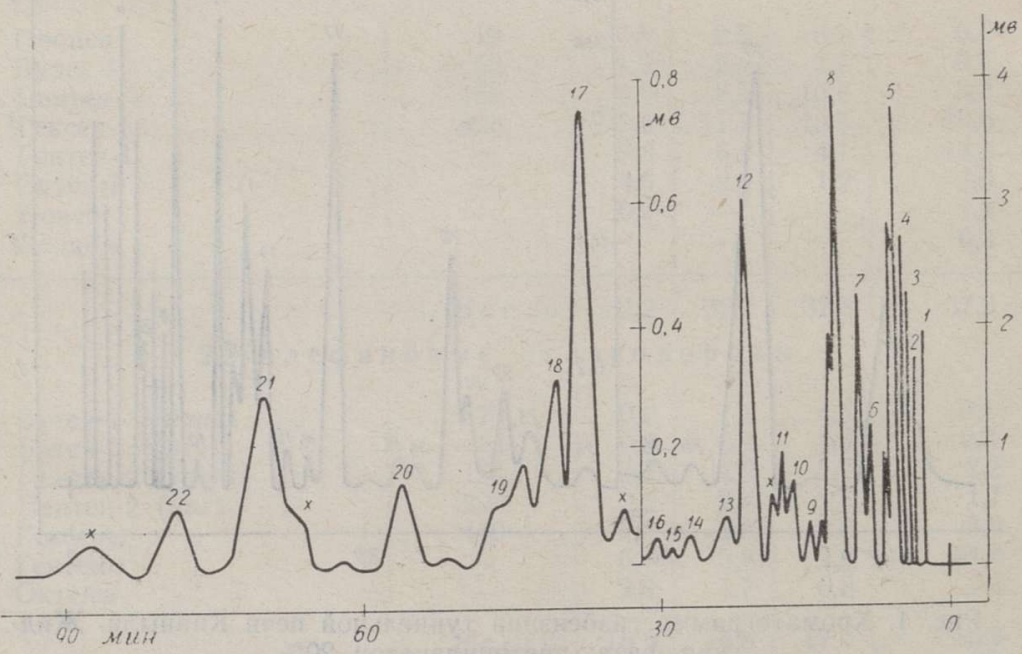

Рис. 3. Хроматограмма фракцни олефиновых углеводородов. Жидкая фаза: дифенилформамид $20 \%$.

1 - воздух; 2 - пентан; 3 - пентен-1; 4 - гексан; 5 - гексен-1;

6 - пиклогексен; 7 - октан; 8 - октен-1; 9 - метилциклогексен;

10 - этнлциклогексан; 11 - нонан; 12 - нонен-1; 13 - нонен-2;

14 - этилциклогексен; 15 - пропилциклогексан; 16 - декан; 17 -

децен-1; 18 - децен-2; 19 - пропилциклогексен; 20 - ундекан; 21 - ундецен-1; 22 - ундецен-2. 
Нанболее трудной задачей является ндентнфнкацня олефнновых углеводородов и циклоолефинов. С помощью соответетвуюших эталонов были ндентифицированы 1-олефины с нормальной цепью. Пики нзомеров 2- и 3-олефннов совпадают на хроматограмме, в связн с чем приходится ограничиваться их суммарным определением. Прнсутствующие во фракцнн парафнновые углеводороды идентифнцируемы. Часть нафтеновых углеводородов имеет одинаковые времена удерживания с олефинами и поэтому определяется совместно с ними: Циклоолефиновые углеводороды можно определить отдельно.

Для определения компонентов в ароматической фракции в качестве жидкой фазы использовали $\beta, \beta^{\prime}$-тнодипрописннтрил (см. табл. 2), коэффициент селективности ( $(\delta)$ которого, для алкнлбензолов по отношению к парафинам, равен прнблизительно $16\left[{ }^{6}\right]$. Эта полярная жидкая фаза применялась для выделення ароматических углеводородов от неароматическнх, но с успехом может быть прнменена также для разделения самнх ароматнческих углеводородов.

На рис. 4 нзображена хроматограмма ароматнческнх углеводородов тяжелого бензина.

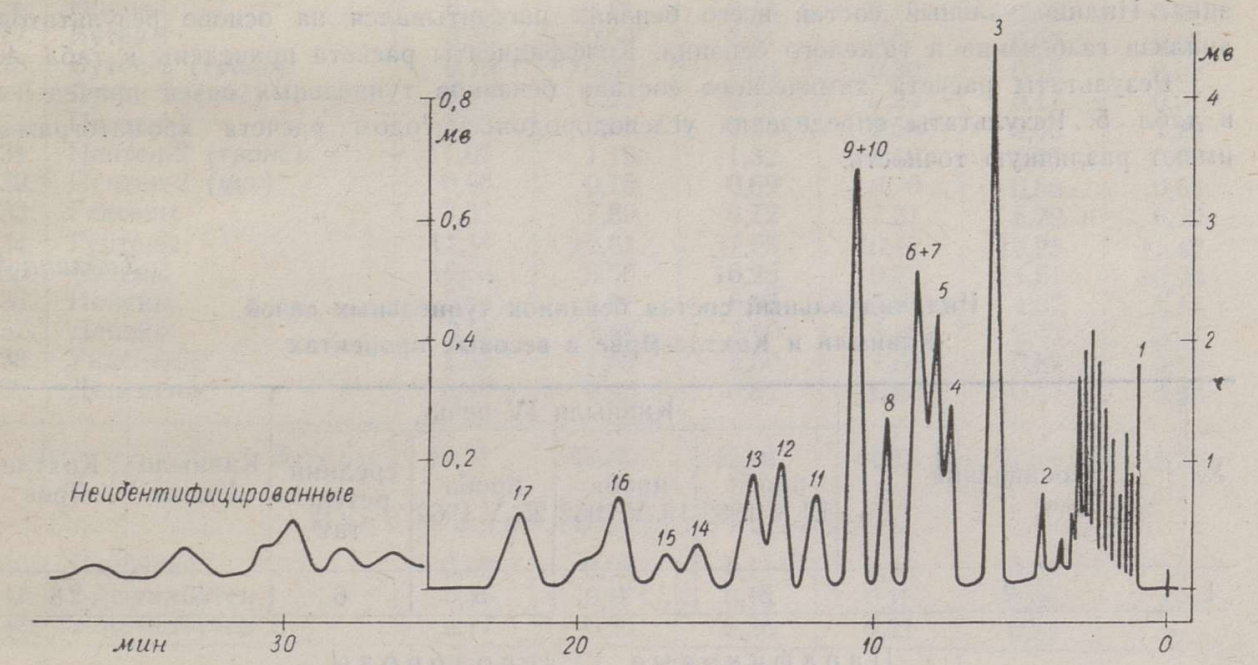

Рнс. 4. Хроматограмма фракцни ароматических углеводородов. Жидкая фаза: $\beta, \beta^{\prime}$-тиодипропионитрил. Температура $150^{\circ} \mathrm{C}$.

1 - воздух; 2 - бензол; 3 - метнлбензол; 4 -метилтнофен; 5 - этнлбензол; 6 - 1,3-диметнлбензол; 7 - 1,4-днметилбензол; 8- пропнлбензол; 9 - 1,2-днметилбензол; 10 - 1 -метил-3-этнлбензол; $11-1,3,5$-триметнлбензол; 12 1 -метил-2-этилбензол; $13-1,2,4$-триметилбензол; $14-1$-метил-2-пропилбензол; 15 - 1,4-диметил-2-этилбензол; 16 -- 1,2,3-трнметнлбензол; 17 - индан.

Результаты анализа ароматических углеводородов контролнровались и уточнялись с помощью четвертой колонки, где в качестве жидкой фазы был полиэтиленглнколь 4000. По полярности полиэтнленгликоль находнтся между дифенилформамидом и $\beta, \beta^{\prime}$-тиодипропионитрилом.

Кроме опнсанной методики применялось также непосредственное определение аро. матическнх соедннений нз суммарной исходной смесн. К исходной пробе добавляли по весу 1 -2\%-ного мезитилена в качестве внутреннего стандарта, ароматические углеводороды анализнровались на колонке с $\beta, \beta^{\prime}$-тиодипропионитрилом.

Для корректирования результатов расчета хроматограмм предварительно были проведены колнчественные анализы с эталонными смесями различного состава в целях выяснення необходимости внесения поправочного коэффициента. Было выяснено, что велнчина поправочных коэффициентов невелика $(\varphi=0,95-1,05)$, в связи с чем она не учнтывалась. Исключенне составляло определение индана, прн котором поправочный коэффнциент, равнын̈ 1,3, был учтен. Это согласуется с даннымн других работ [7]. 


\section{Данные для расчета состава бензинов туннельных печей} в весовых процентах

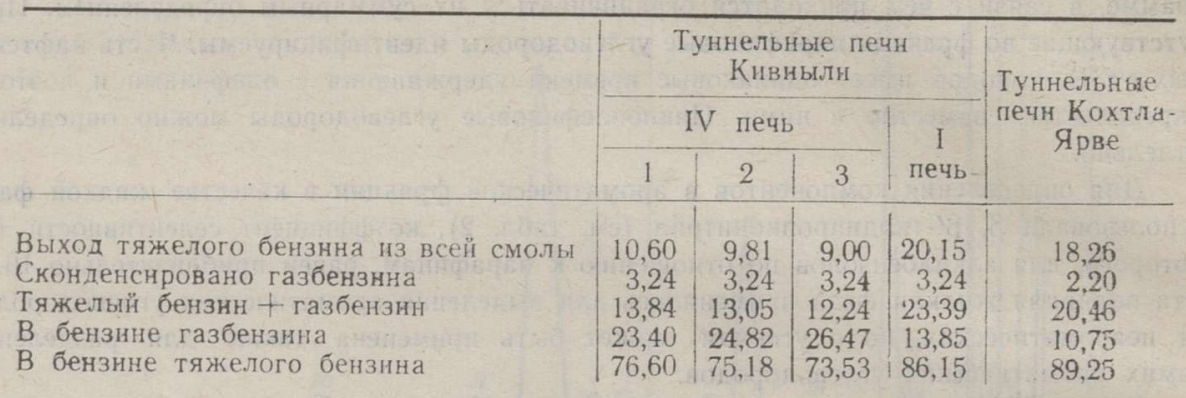

Вышеуказанным методом был определен нндивидуальный состав тяжелого бензнна. Инднвидуальный состав всего бензина рассчнтывался на основе результатов аналнза газбензнна и тяжелого бензнна. Коэффнцненты расчета прнведены в табл. 4.

Результаты расчета хнмнческого состава бензинов туннельных печей приведены в табл. 5. Результаты определения углеводородов методом расчета хроматограмм имеют различную точность.

Tаблича 5

Индивидуальный состав бензинов туннельных печей Кнвиыли и Кохтла-Ярве в весовых процентах

\begin{tabular}{|c|c|c|c|c|c|c|c|}
\hline \multirow[b]{2}{*}{ o } & \multirow[b]{2}{*}{ Соединения } & \multicolumn{4}{|c|}{ Кнвнылн IV печь } & \multirow[b]{2}{*}{$\begin{array}{c}\text { Кнвнылн } \\
\text { f печь }\end{array}$} & \multirow[b]{2}{*}{$\begin{array}{l}\text { Коктла } \\
\text { Ярве }\end{array}$} \\
\hline & & $\begin{array}{c}\text { проба } \\
\text { 12. V } 1962\end{array}$ & $\begin{array}{l}\text { проба } \\
\text { 19. V } 1962\end{array}$ & $\begin{array}{c}\text { проба } \\
25 . \text { V } 1962\end{array}$ & $\begin{array}{c}\text { средннй } \\
\text { резуль- } \\
\text { тат }\end{array}$ & & \\
\hline
\end{tabular}

Парафнновые углеводороды
1. Этан
2. Пропан
3. Бутан
4. Пентан
5. Гексан
6. Гептан
7. Октан
8. Нонан
9. Декан
10. Ундекан
11. Додекан

\begin{tabular}{|l|l|l|l|l|l|l} 
& 0,05 & & & & & - \\
& 0,14 & 0,15 & 0,16 & 0,02 & & - \\
& 0,49 & 1,07 & 1,26 & 0,91 & 0,08 & - \\
& 1,81 & 2,88 & 3,92 & 2,88 & 3,03 & 1,69 \\
& 3,82 & 3,86 & 4,06 & 3,92 & 4,41 & 3,81 \\
& 4,86 & 3,72 & 3,19 & 3,92 & 4,78 & 4,98 \\
& 4,23 & 3,66 & 3,72 & 3,87 & 4,11 & 4,59 \\
& 3,66 & 3,00 & 3,09 & 3,25 & 2,44 & 2,71 \\
& 1,55 & 1,50 & 1,84 & 1,63 & 1,31 & 1,54 \\
& 1,00 & 0,68 & 0,96 & 0,88 & 0,87 & 1,07 \\
& 0,31 & 0,23 & 0,07 & 0,21 & 0,17 & 0,27 \\
\hline \multirow{1}{*}{ B c r o } & 21,92 & 20,75 & 22,27 & 21,64 & 21,94 & 20,94
\end{tabular}

Изопарафиновые углеводороды

\begin{tabular}{l|l|l|l|l|l|l|l} 
12. & 2-Метнлоутан & 0,12 & 0,25 & 0,42 & 0,26 & 0,20 & - \\
13. & 2-Метнлтексан & 0,02 & 0,02 & - & 0,01 & - & - \\
14. & 2-Метнлгептан & 0,04 & 0,08 & 0,01 & 0,04 & - & 0,12 \\
15. & 2-Метнлоктан & 0,10 & 0,12 & 0,10 & 0,11 & 0,04 & 0,17 \\
16. & 2-Метнлнонан & 0,18 & 0,22 & 0,22 & 0,21 & 0,21 & 0,07 \\
17. & 2-Метнлдекан & 0,08 & 0,08 & 0,04 & 0,07 & 0,10 & - \\
18. & 2-Метнлундекан & 0,04 & 0,01 & - & 0,02 & - & 0,36
\end{tabular}


Циклопарафинновые углеводороды

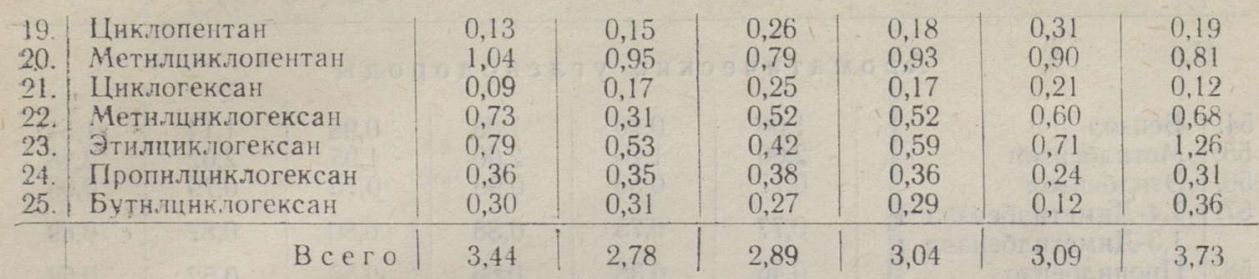

Неустановленные нзонарафнновые н ииклопарафнновые углеводороды

\begin{tabular}{r|r|r|r|r|r|r} 
Bсего & 0,77 & 0,23 & 0,51 & 0,50 & 0,17 & 0,27 \\
$\begin{array}{r}\text { Cунма предельных уг - } \\
\text { леводородов }\end{array}$ & 26,71 & 24,54 & 26,46 & 25,90 & 25,75 & 25,30
\end{tabular}

Олефнновые углеводороды

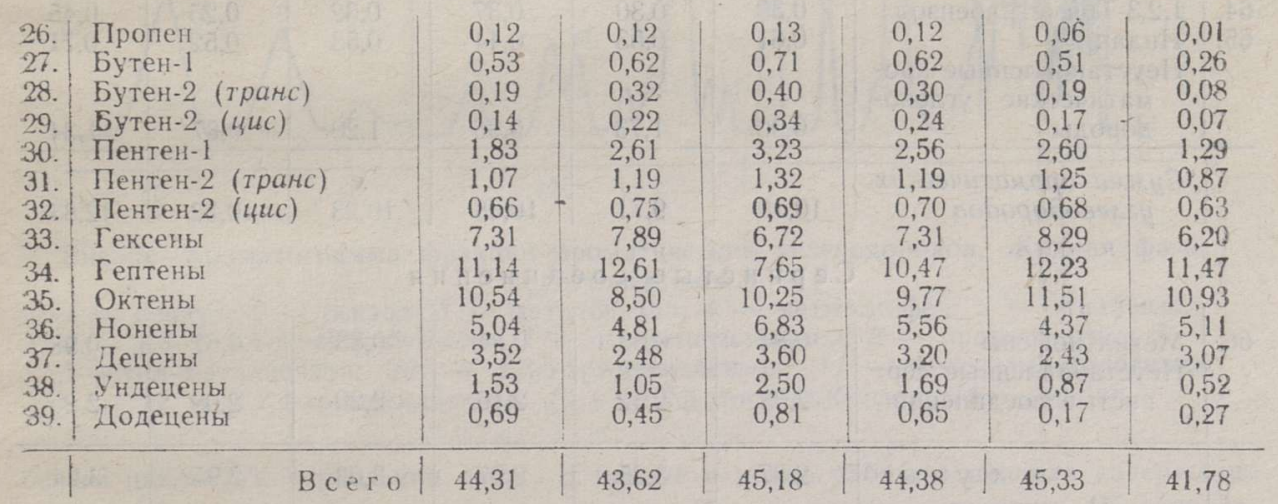

Изоолефинов ые углеводороды

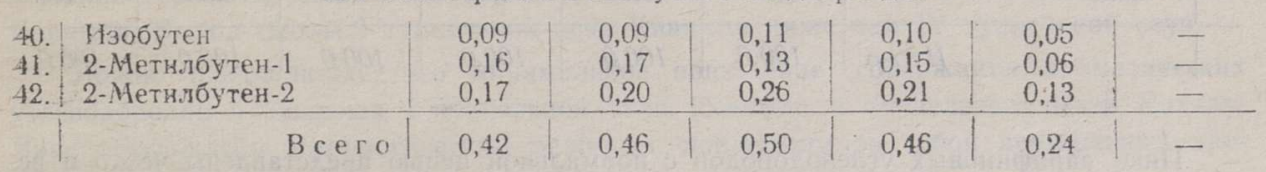

Циклоолефнновые углеводороды

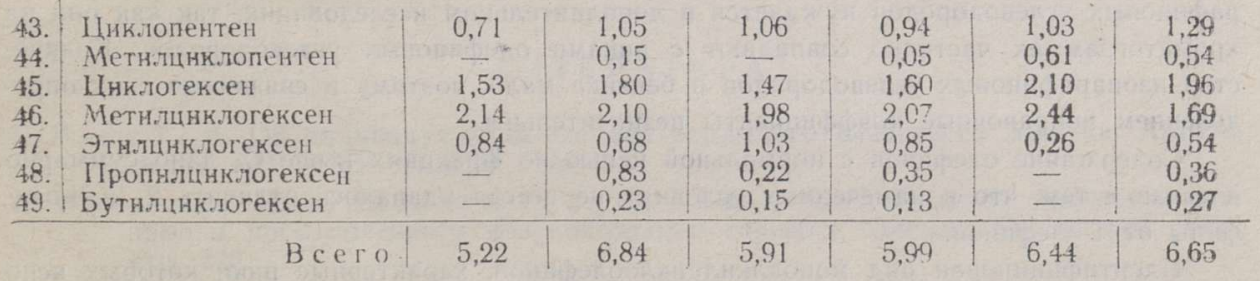

Диолефиновые углеводороды

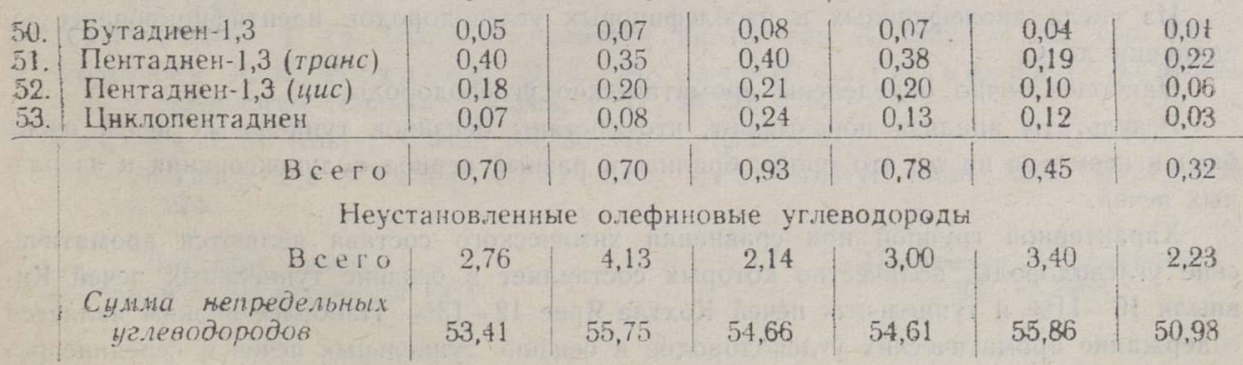




\begin{tabular}{l|l|l|l|l|l|l|l|l|}
\hline 1 & 2 & 3 & 4 & 5 & 6 & 7 & 8 \\
\hline
\end{tabular}

Ароматические углеводороды

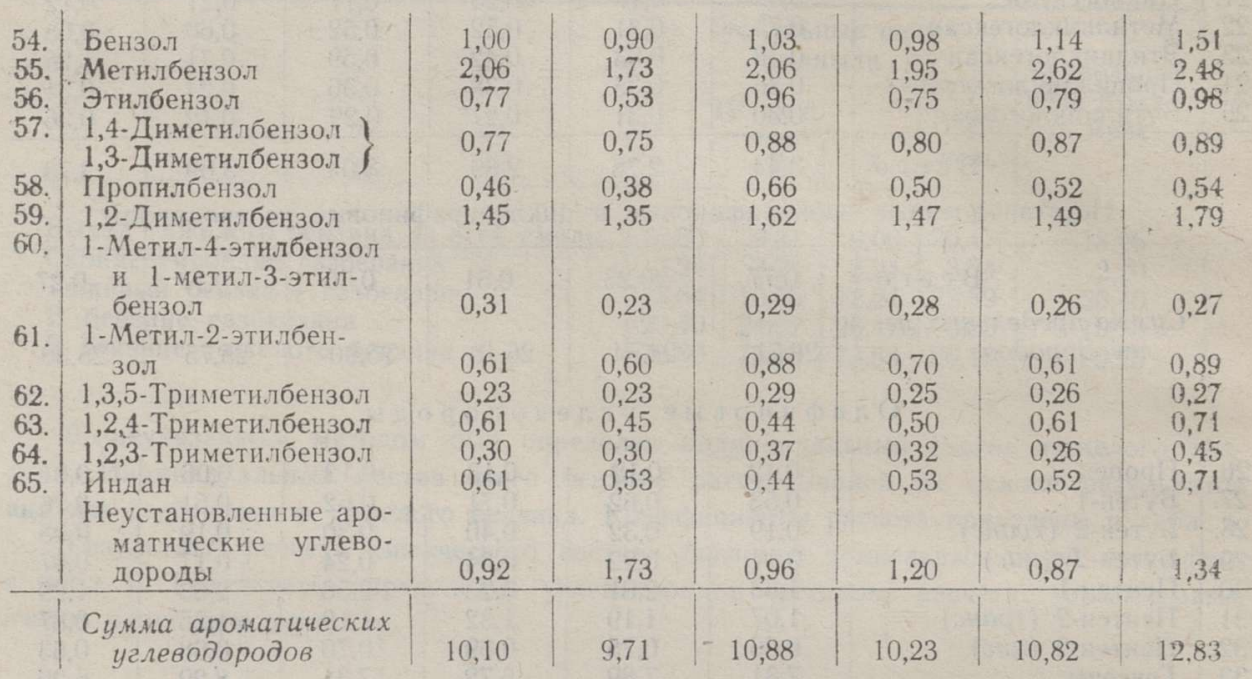

Сернистые соединення

\begin{tabular}{|c|c|c|c|c|c|c|}
\hline $\begin{array}{l}\text { Метилтиофены } \\
\text { Неустановленные сер. } \\
\text { нистые соедннения }\end{array}$ & $\begin{array}{l}0,84 \\
2,03\end{array}$ & $\begin{array}{l}0,83 \\
2,42\end{array}$ & $\begin{array}{l}0,81 \\
2,16\end{array}$ & $\begin{array}{l}0,83 \\
2,20\end{array}$ & $\begin{array}{l}0,87 \\
2,08\end{array}$ & $\begin{array}{l}0,98 \\
2,25\end{array}$ \\
\hline $\begin{array}{l}\text { Сумма } \\
\text { Потерн в хроматогра- } \\
\text { фни }\end{array}$ & $\begin{array}{l}2,87 \\
6,91\end{array}$ & $\begin{array}{l}3,25 \\
6,75\end{array}$ & $\begin{array}{l}2,97 \\
5,03\end{array}$ & $\begin{array}{l}3,03 \\
6,23\end{array}$ & $\begin{array}{l}2,95 \\
4,62\end{array}$ & $\begin{array}{l}3,24 \\
7,65\end{array}$ \\
\hline Нтого & 100,0 & 100,0 & 100,0 & 100,0 & 100,0 & 100.0 \\
\hline
\end{tabular}

Пики парафиновых углеводородов с нормальной цепью представлены четко и результаты расчета по ним можно считать вполне надежнымн. Содержанне цнкдопарафнновых углеводородов нуждается в дополнительном исследованни, так как они на хроматограммах частично совпадают с пиками олефиновых углеводородов. Колнчество изопарафнновых углеводородов в бензине мало, поэтому и связанные с их определением поправочные коэффнцненты незначнтельны.

Содержанне олефинов с нормальной цепью во фракциях выше $\mathrm{C}_{6}$ дано суммарно в связи с тем, что в намеченных условиях не всегда удавалось отличить 2- и 3-олефнны от 1-олефинов.

Идентифицирован ряд моноалкнлцнклоолефннов, характерные пикн которых ясно отлнчаются от пнков других олефнновых углеводородов.

Нз числа диолефиновых и изоолефиновых углеводородов идентифнцнрованы соедннения до $\mathrm{C}_{5}$.

Нанболее точно определены ароматические углеводороды.

Результаты анализа показывают, что составы бензннов туннельных печей очень близки несмотря на то, что пробы брались в разный период полукоксовання н из разных печей.

Характерной группой при сравнении химического состава являются ароматнческне углеводороды, количестьо которых составляет в бензине туннельных печей Қивныли 10-11\% и туннельных печей Кохтла-Ярве $12-13 \%$. Нанболее ннзкнм является содержанне ароматнческнх углеводородов в бензнне туннельных печей в середнве ра- 


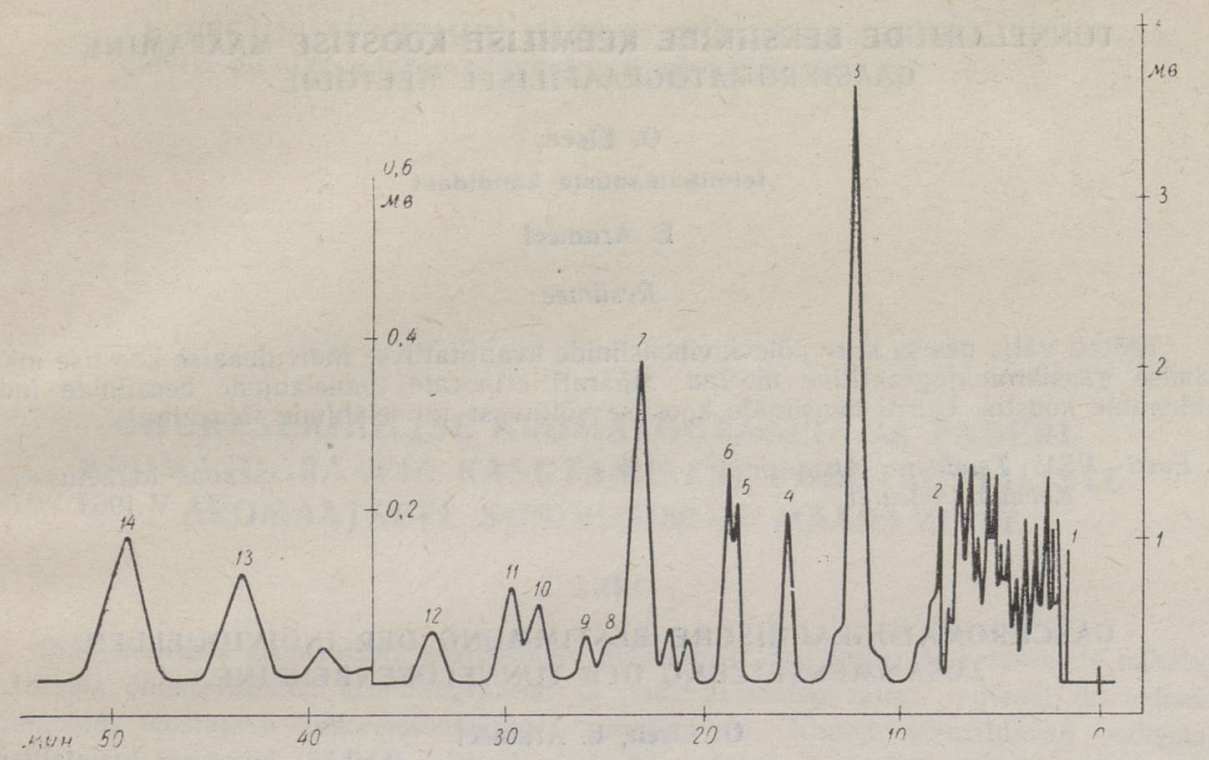

Рис. 5. Хроматограмма фракцни ароматических углеводородов. Жидкая фаза: полиэтиленглюкол.

1 - воздух; 2 - бензол; 3 - метилбензол; 4 - метилтиофен; 5 - этилбензол;

6 - 1,3- и 1,4-диметилбензолы; 7 - 1,2-диметилбензол; 8 - пропилбензол; 9 -

I-метнл-3-этилбензол; 10 - 1,3,5-триметилбензол; 11 - 1-метил-2-этилбензол; 12 - 1,2,4-триметилбензол; 13 - 1,2,3-триметилбензол; 14 - индан.

Ђочего цикла (IV туннельная печь). В начале и конце рабочего периода содержание ароматических углеводородов немного выше. По сравнению с данными IV печи содержание ароматических углеводородов несколько выше в бензине I туннельной печи Кивиыли. Выход смолы I туннельной печи Қивиыли ниже чем IV туннельной печи.

Можно предполагать, что минимальное повышение содержания ароматических углеводородов в бензннах I туннельной печи Қнвиыли и туннельных печей КохтлаЯрве обусловлено технологическим режимом, повлекцим за собой повышенный крекинг продуктов полукоксования.

Л И Т Е А T Y P A

1. Р анг С. А. Об нндивкдуальном составе эстонского сланцевого бензина. Автореферат, АН. ЭССР, Таллин, 1961.

2. Николаев Г. А., Шелоумов В. В., Тянав И. В. Вопросы техники и экономики промышленного полукоксования горючих сланцев. Сб. второй, 1959, стр. 246.

3. Шелоумов В. В., Николаев Г. А., В алландер Б. В. В том же сборнике, стр. 223.

4. Ли пп м а а Э. Т. Тр. Таллинек. политехн. нн.-та. Сер. А, 1962, № 195, стр. 109.

5. Топчиев А. В., И схаков а Э. Х., Мусаев И. А., Гальперн Г. Д. Химия и технология топлива и масел, т. 11, № 26, 1957.

6. T ел ле у H. M. Analyt. Chem., vol. 30, No. 1, 1958, p. 2.

7. Ta Chuang Lo Chang, Clarence Karr. Analyt. Chim. Acta, № 21, 1959, p. 274.

Ннститут химии

Академии маук Эстомской ССР
Поступила в редакцию

23. V 1963 


\section{TUNNELAHJUDE BENSIINIDE KEEMILISE KOOSTISE MÄÄRAMINE GAASIKROMATOGRAAFILISEL MEETODIL}

o. Eisen, tehnikateaduste kandidaat

E. Arumeel

\section{Resümee}

Töötati välja uus ja kiire põlevkivibensiinide kvantitatiivse individuaalse koostise määramise gaasikromatograafiline meetod. Määrati erinevate tunnelahjude bensiinide individuaalne koostis. Uuriti bensiinide koostise sōltuvust tunnelahjude töörežiimist. Eesti NSV Teaduste Akadeemia
Keemia Instituut
Saabus toimetusse 23. V 1963

\section{GASCHROMATOGRAPHISCHE BESTIMMUNG DER INDIVIDUELLEN ZUSAMMENSETZUNG DER TUNNELOFENBENZINE}

\section{o. Eisen, E. Arumeel}

\section{Zusammenfassung}

Es wurde eine neue schnelle gaschromatographische Methode für die Bestimmung der individuellen quantitativen Zusammensetzung der Brennschieferbenzine ausgearbeitet.

Durch die beschriebene Methode wurde in den Benzinen der Tunnelöfen von Kiviōli und Kohtla-Jărve die individuelle Zusammensetzung quantitativ identifiziert. Es wurden Zusammenhänge zwischen dem Arbeitsregime der Tunnelöfen und der chemischen Zusammensetzung der Benzine untersucht.

\section{Institut für Chemie}

der Akademie der Wissenschaften der Estnischen SSR
Eingegangen am 23. Mai 1963 